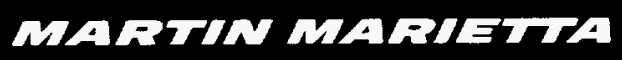

.

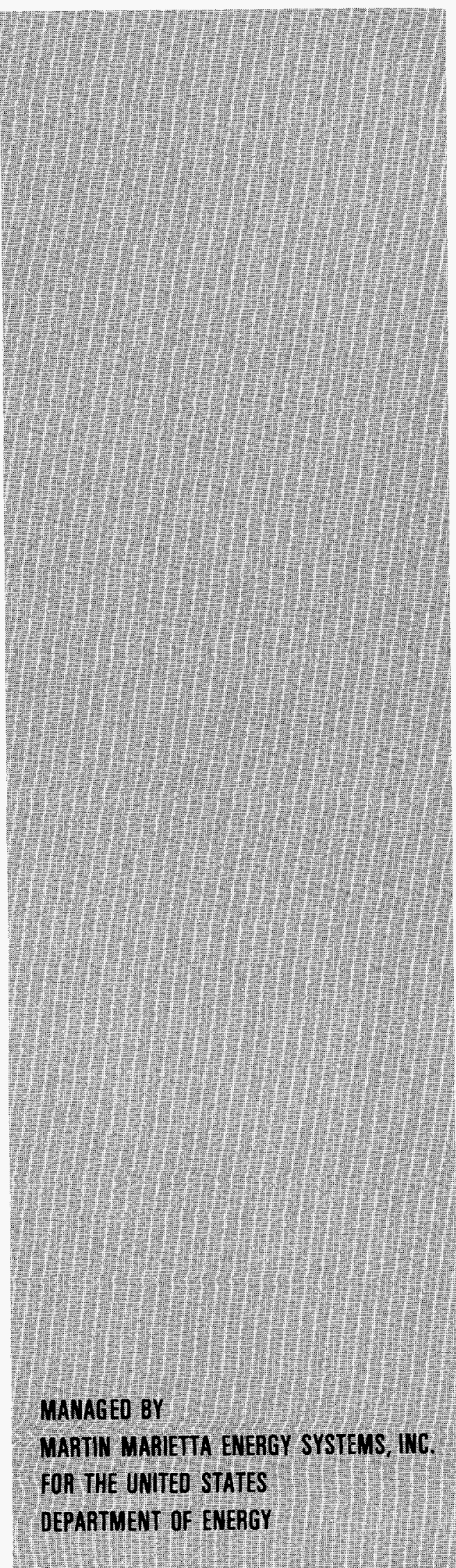

National Security Program Office

\section{IAEA Workshop and Field Trial at the Oak Ridge K-25 Site}

\author{
D. M. Hembree, Jr. \\ H. H. Ross \\ J. A. Carter
}

March 1995
DISTRIBUTION OF THIS DOCUMENT IS UNLIMITED

GH 


\section{DISCLAIMER}

This report was prepared as an account of work sponsored by an agency of the United States Government. Neither the United States Government nor any agency thereof, nor any of their employees, makes any warranty, express or implied, or assumes any legal liability or responsibility for the accuracy, completeness, or usefulness of any information, apparatus, product, or process disclosed, or represents that its use would not infringe privately owned rights. Reference herein to any specific commercial product, process, or service by trade name, trademark, manufacturer, or otherwise, does not necessarily constitute or imply its endorsement, recommendation, or favoring by the United States Government or any agency thereof. The views and opinions of authors expressed herein do not necessarily state or reflect those of the United States Government or any agency thereof. 


\section{DISCLAIMER}

Portions of this document may be illegible in electronic image products. Images are produced from the best available original document. 


\title{
IAEA Workshop and Field Trial at the Oak Ridge K-25 Site
}

D. M. Hembree, Jr.

H. H. Ross

J. A. Carter

Martin Marietta Energy Systems, Inc.

Contract \#80Y-HHM52V

\author{
Prepared by the \\ National Security Program Office \\ Oak Ridge K-25 Site \\ Oak Ridge, Tennessee 37831-7312 \\ managed by \\ MARTIN MARIETTA ENERGY SYSTEMS, INC. \\ for the \\ U.S. DEPARTMENT OF ENERGY \\ under Contract DE-ACO584OR21400
}



CONTENTS

\section{Page}

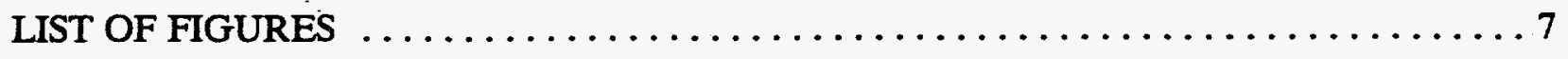

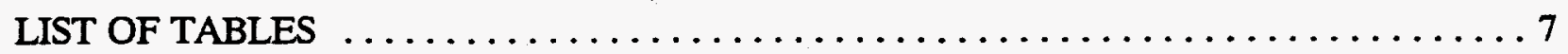

EXECUTIVE SUMMARY $\ldots \ldots \ldots \ldots \ldots \ldots \ldots \ldots \ldots \ldots \ldots \ldots$

1. INTRODUCTION $\ldots \ldots \ldots \ldots \ldots \ldots \ldots \ldots \ldots \ldots \ldots \ldots \ldots \ldots \ldots \ldots \ldots \ldots \ldots$

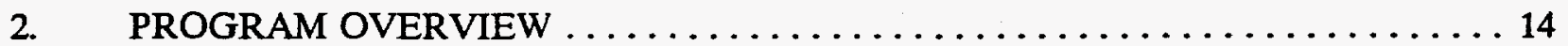

2.1 TRAINING WORKSHOP EXERCISE $\ldots \ldots \ldots \ldots \ldots \ldots \ldots \ldots \ldots \ldots \ldots \ldots$

2.2 ENVIRONMENTAL SAMPLING CONSIDERATIONS $\ldots \ldots \ldots \ldots \ldots 15$

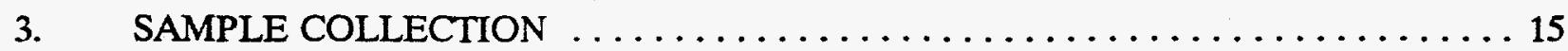

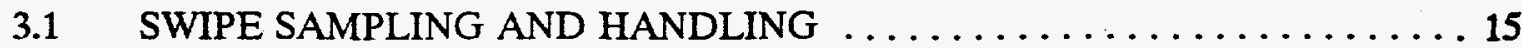

3.2 VEGETATION AND SOIL SAMPLING AND HANDLING $\ldots \ldots \ldots \ldots 16$

3.3 WATER, SEDIMENT, AND BIOTA SAMPLING AND HANDLING . . . . 16

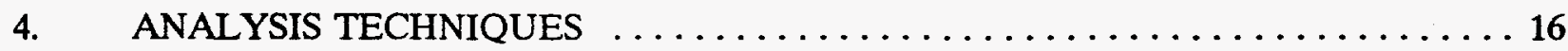

$4.1 \quad$ DESCRIPTION OF SAMPLING ANALYSIS $\ldots \ldots \ldots \ldots \ldots \ldots \ldots \ldots 16$

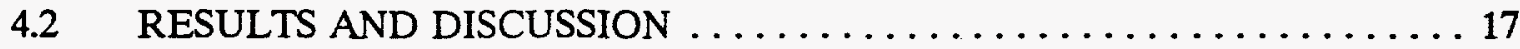

Appendix A AGENDA, ATTENDEES, AND SAMPLE TEAM COLLECTION ASSIGNMENTS FOR THE IAEA ENVIRONMENTAL MONITORING FIELD

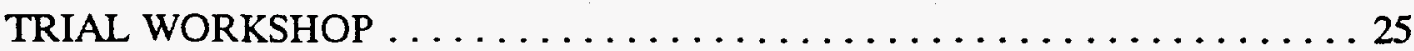

Appendix B. SWIPE SAMPLE COLLECTING PROCEDURES $\ldots \ldots \ldots \ldots \ldots \ldots \ldots . \ldots \ldots$

Appendix C. PROCEDURE FOR VEGETATION AND SOIL SAMPLING . . . . . . . 37

Appendix D. AQUATIC SAMPLING METHODS $\ldots \ldots \ldots \ldots \ldots \ldots \ldots \ldots \ldots$

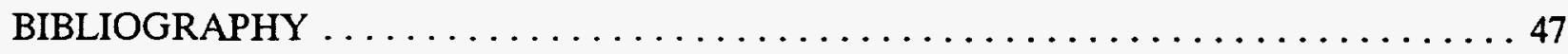

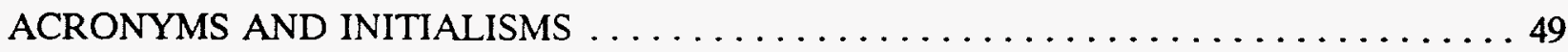





\section{LIST OF FIGURES}

No.

Page

1

Map showing the Oak Ridge Reservation and location of the three

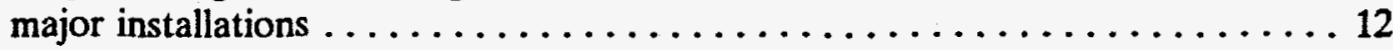

Oak Ridge K-25 Site (northwest view)

13

K-25 Site area showing locations where samples were taken

.21

\section{LIST OF TABLES}

No.

Page

Uranium bulk analysis on vegetation: ashed and almost completely dissolved

Uranium bulk analysis on vegetation: acid leached

Particles isolated from vegetation 18

Oak Ridge field trials water and sediment samples

Oak Ridge field trials water filter and sediment samples 



\section{EXECUTIVE SUMMARY}

In March 1994, members of the International Safeguards Department in the National Security Program Office (NSPO) hosted an environmental monitoring field trial workshop for International Atomic Energy Agency (IAEA) inspectors. The workshop was held at the Oak Ridge K-25 Site and its primary purpose was to train the inspectors in the techniques needed for effective environmental sample collection and handling.

The workshop emphasized both sampling theory and practice. First, detailed techniques for swipe, vegetation, soil, biota, and water-associated sampling were covered in the classroom. Subsequently, the inspectors were divided into three groups for actual sample collection in and around the K-25 locale. The collected samples were processed by the Department of Energy (DOE) Network of Analytical Laboratories using established analytical techniques. This activity is part of the IAEA "Programme $93+2$ " assessment of measures to enhance IAEA safeguards.

Although the main purpose of the training exercise was to familiarize inspectors with tested sample collection methodologies, a secondary function was to provide environmental analytical data from the K-25 Site for analysis. The goal was to impart sufficient expertise to the inspectors so that they could participate effectively in a number of international field trial assessments. Also, as a result of the workshop, a short training video was prepared describing the technique of "swipe sampling."

Results are now available for the vegetation, sediment, water, and soil samples. In essentially all cases, vegetation samples collected at various distances from the site center exhibit extremely low levels of uranium $\left(10^{-9} \mathrm{gU} / \mathrm{g}\right.$ for leached samples $)$. However, these samples show uranium enrichment out to $8 \mathrm{~km}$ from the site. The measured ${ }^{235} \mathrm{U}{ }^{234} \mathrm{U}$ ratios, ranging from 82 to 117 , presumably suggest that both low enriched uranium (LEU) and highly enriched uranium (HEU) have been produced in this facility. Particulate measurements carried out on the vegetation samples show a ${ }^{235} \mathrm{U}$ enrichment ranging from 0.63 to 18.94 at. \%, which confirms this suggestion. Filtered water samples show a slight ${ }^{235} \mathrm{U}$ enrichment upstream and up to a $2 \%$ enrichment downstream. Companion sediment samples displayed a somewhat lower ${ }^{235} \mathrm{U}$ enrichment. It should be noted that all of the uranium concentrations and isotopic results from the workshop field trial exercise are in close agreement with corresponding results previously reported in the Oak Ridge Reservation Environmental Report for 1992 (ES/ESH-31/N1/V2).

Perhaps the most interesting and revealing environmental monitoring result from the K-25 Site was associated with the water and sediment samples. One of the field assignments was the off-site collection of filtered water samples from streams that flowed into and out of the protected area of the site. The expectation was that enriched uranium isotopics would be seen in the water and sediments but that little else of safeguards significance would be found. Surprisingly, downstream samples also showed very low levels of plutonium having an isotopic ratio for ${ }^{239} \mathrm{Pu} /{ }^{40} \mathrm{Pu}$ of 18.45 . This ratio is significantly higher then the 5.5 value that is expected from normal fallout plutonium.

This unexpected result indicated that either an error had been made in the analysis of the samples or that some unknown activity involving plutonium had been carried out at the K-25 Site. After checking the credibility of the analytical results, a meeting was held with K-25 Site management to discuss the results. Management explained that several years ago, some Hanford reactor return material containing very low levels of plutonium was brought to the K-25 Site. As a result of several small release mechanisms during cascade upgrade activities, some of this plutonium was eventually deposited into two small ponds located near the stream that was sampled during the field trial exercise. On the day the samples were taken, heavy rain was experienced in the area. Under these conditions, liquid in the ponds can overflow with subsequent material transfer between the pond and stream. Additional checking showed that the isotopic composition of the detected plutonium is consistent with Hanford reactor return material, thus confirming the source of the environmental plutonium. 
Overall, the environmental sample results from the K-25 Site demonstrated clearly and decisively that HEU and LEU enrichment operations can be detected with both bulk and particulate techniques. The plutonium result is extremely significant in that it obviously supports the concept that Environmental Methods (EMs) have substantial application in the detection of unexpected (undeclared) activities at a nuclear facility. It also suggests how an EM "anomaly" might be handled: (1) check the analysis and (2) meet with the facility operator to explore possible explanations for the observed results. 


\section{INTRODUCTION}

Environmental Methods have been proposed to further strengthen nuclear safeguards by the IAEA Standing Advisory Group on Safeguards Implementation (SAGSI). A consultants' group, convened by the SAGSI, evaluated the potential of EMs and conclusively determined that environmental techniques could be used to detect nuclear facility signatures. Signatures of facilities could be obtained by combining concentration methods with highly sensitive analytical techniques to measure signatures on swipe surfaces, vegetation, water, sediments, and biota. The establishment of the presence of signature contaminants along with concomitant isotopic and elemental ratios could be employed to establish the existence of a declared and, most importantly, an undeclared nuclear operation. The consultants' group recommended that a series of field trials be conducted around known facilities to demonstrate the capability of EMs.

Following these recommendations, the IAEA developed in late 1993 the plans for a series of environmental monitoring field trials. These field trials are to be carried out to establish and document: (1) significant environmental signatures for enrichment, reprocessing and reactor operations; (2) procedures for sampling and analysis; and (3) evaluating procedures for effectiveness, cost, and timeliness under varied conditions.

In March 1994, NSPO's International Safeguards group in Oak Ridge hosted an environmental monitoring field trial workshop for IAEA inspections. The workshop was held at the Oak Ridge K-25 Site, a former major uranium enrichment site. The K-25 Site, one of three major Oak Ridge DOE complexes, is on the Oak Ridge Reservation (ORR), located in East Tennessee. The K-25 Site has been managed by Martin Marietta Energy Systems, Inc., since 1984 (Fig. 1). The site is in the southern mixed hardwood forest zone and has a diverse collection of trees, shrubs, and other plant life. The climate is moderate having an average rainfall of $-1.4 \mathrm{~m}$. Area winds are light and primarily follow the valley and ridge topography (Fig. 2).

Until 1985, the primary mission of the K-25 Site was the enrichment of the ${ }^{235} \mathrm{U}$ isotope in uranium hexafluoride $\left(\mathrm{UF}_{6}\right)$ using the gaseous diffusion process. In addition to operating the diffusion cascade, the K-25 Site was involved in developing and demonstrating two other enrichment techniques: the gas centrifuge process and the atomic vapor laser isotopic separation (AVLIS) method. Although these enrichment processes are now inactive, the equipment is still in place making K-25 an excellent location for an IAEA inspector training workshop. Currently (since 1991), the Toxic Substances Control Act (TSCA) Incinerator also operates at the K-25 Site to destroy, by combustion, uranium-contaminated waste materials. Although previous discharges from the K-25 Site have included source terms from residual contamination, waste storage and disposal, and site remediation and site operational support activities, TSCA is now the primary source of radiological emissions in the area.

The K-25 Site maintains environmental sampling and analysis programs to fully comply with DOE, Environmental Protection Agency (EPA), and the State of Tennessee environmental regulations. Details are fully described in the Oak Ridge Reservation Annual Site Environmental Report for 1993 (ES/ESH-47). The information presented in this annual report includes:

- $\quad$ airborne discharges,

- ambient air monitoring,

- meteorological monitoring, 


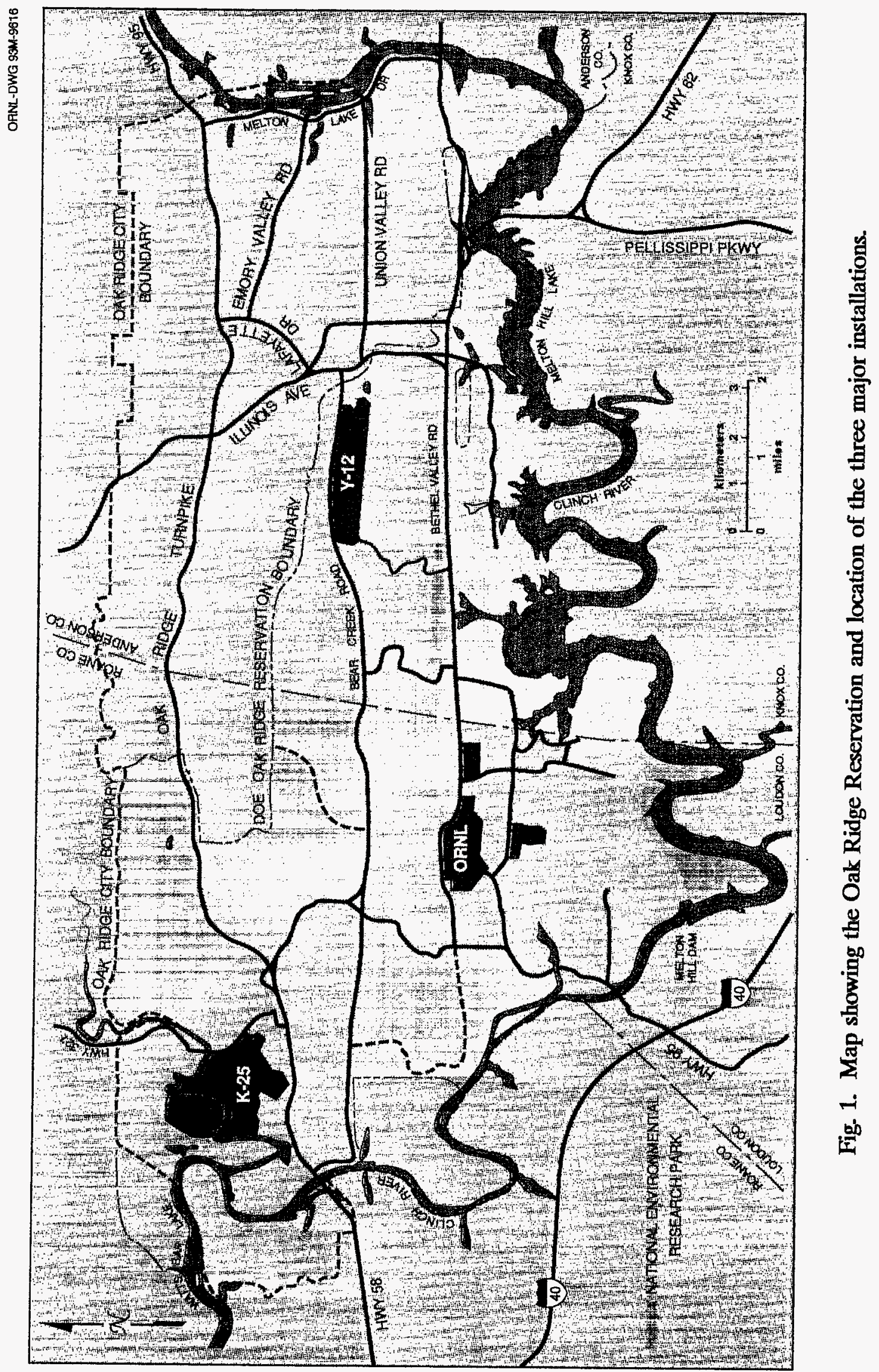




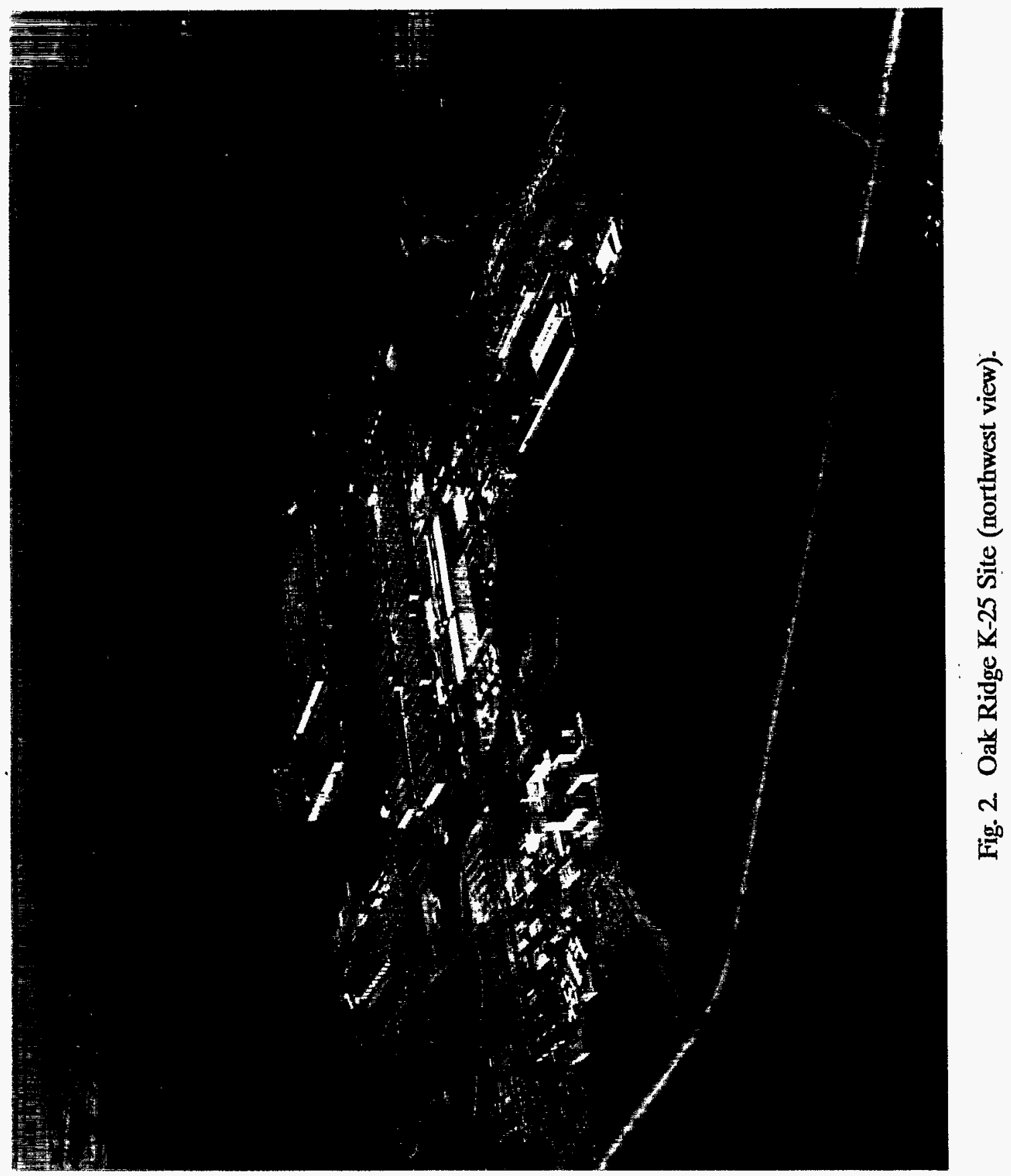


- external radiation monitoring,

- hydrological and surface water monitoring, and

- $\quad$ effluent monitoring.

Quality assurance at each DOE site, particularly for environmental compliance, is extensive and includes many of the following practices:

- use of standard operating procedures (SOPs) for sample collection and analysis;

- use of chain-of-custody and sample tracking, procedures to ensure traceability, defensibility, and integrity of samples and data;

- instrument standardization, calibration, and verification;

- $\quad$ background measurements at the sample source and in the laboratory;

- resolution checks and detector alignment for determination of gamma emitter radionuclides;

- $\quad$ yield determinations for radiochemical procedures;

- duplicate analyses for precision checks;

- technician and analyst training;

- $\quad$ spiked and surrogate sample analysis to determine matrix effects;

- $\quad$ sample preservation, handling, and decontamination; and

- use of surveillance procedures.

\section{PROGRAM OVERVIEW}

\subsection{TRAINING WORKSHOP EXERCISE}

From March 22-25, 1994, the International Safeguards group hosted an environmental monitoring field trial workshop for IAEA inspectors (see Appendix A). The workshop was held at the K-25 Site (formerly the Oak Ridge Gaseous Diffusion Plant) and its primary purpose was to train the inspectors in the techniques needed for effective environmental sample collection and handling. The workshop emphasized both sampling theory and practice. Detailed techniques for swipe, vegetation, soil, biota, and water-associated sampling were covered in the classroom. Subsequently, the inspectors were divided into three groups for sample collection in and around the K-25 Site; the three-team approach corresponded to the three broad types of EM samples to be collected. Basically, these were vegetation and soil sampling and handling; swipe sampling and handling; and water sediment and biota sampling and handling. Samples were processed and collected, using established analytical techniques, by the U.S. Network of Analytical Laboratories (NWAL), composed of laboratories at Oak Ridge National Laboratory, Los Alamos National Laboratory, Savannah River Technology Center, Lawrence Livermore National Laboratory, Pacific Northwest Laboratory, and the Air Force Technical Applications Center (AFTAC). NWAL personnel also participated in the workshop. 


\subsection{ENVIRONMENTAL SAMPLING CONSIDERATIONS}

Uranium enrichment plants, like all practical industrial plants, release small fractions of their process inventory into the atmosphere and surface waters. Sensitive analysis of atmospheric deposition products and surface waters in the vicinity of enrichment plants can detect uranium with isotopic compositions that are distinctly different from the naturally occurring isotopic composition and can determine uranium concentrations in environmental samples.

Although the measured concentrations of uranium in the environment are normally well below those of concern for health and safety reasons, environmental samples potentially are useful for international safeguards applications in detecting undeclared enrichment activities, undeclared enrichment activities at declared sites, and evidence of operations that have produced HEU.

Practically all worldwide uranium enrichment plants process uranium in the form of $\mathrm{UF}_{6}$ gas by gaseous diffusion, centrifugation, or aerodynamic processes. Because of the relatively high volatility of the gas, even at ambient temperatures, it is practically impossible to avoid the release of small quantities into the atmosphere and surface waters. The chemical reactivity of the $\mathrm{UF}_{6}$ gas leads to the formation of a variety of soluble and insoluble forms of uranium in the environment. Some other uranium enrichment processes (e.g., electromagnetic, chemical, and laser) process uranium in the form of chlorides or metal. The uranium compounds from these processes are less volatile at ambient temperatures, but large-scale operations in practical equipment still lead to detectable emissions of uranium through ventilation systems and aqueous waste streams.

The types of environmental samples that should be collected are determined by the nature of the information desired. Air and water samples provide information on current facility effluents; surface dust, stream sediment, and vegetation samples provide historical information on effluents; cloth swipe samples can provide information about process operations. Some uranium is absorbed by vegetation through uptake of groundwater, but the uranium of principal interest in a vegetation sample is deposited on exposed surfaces via atmospheric deposition. Deciduous leaves are excellent integrators of uranium deposition over a growing season. Evergreen needles, properly selected, integrate over two years while tree bark serves as a long-term integrator.

Most useful soil samples are usually surface dusts collected by vacuuming or brushing. Soil cores normally dilute the atmospheric deposits with significant amounts of naturally occurring uranium and, thus, are less desirable as environmental samples. [The average natural concentration of uranium in the earth's crust is 2.7 parts per million ( $\mathrm{ppm}$ ), and relatively common earth samples contain as much as $5-60 \mathrm{ppm}$.]

\section{SAMPLE COLLECTION}

\subsection{SWIPE SAMPLING AND HANDLING}

Swipe samples were taken both inside and outside of the K-25 Site production buildings and gas centrifuge pilot areas by employing AFTAC prepackaged swipe sampling kits and following the protocol procedure (Appendix B). Six swipe samples were taken at each of nine locations by each of the three teams. The protocol and training exercises emphasized measures for preventing crosscontamination during the sampling process and also during the sample packing and shipping operations.

In general, swipes collected inside the process buildings were taken as close to critical points as possible. For any enrichment facility, swipes are recommended around process sampling points, analytical stations, chemical traps, compressors, purge pipe exits, and at semi-on-line monitoring stations. If access is available only outside the process facilities, protected ledges, backs of traffic signs, TV monitoring screens in the vicinity, windshields of on-site vehicles, and other places where airborne dust can accumulate are good candidates for swipe sampling locations. 


\subsection{VEGETATION AND SOIL SAMPLING AND HANDLING}

Uranium may be incorporated into vegetation via two routes: (1) uptake from soil and water and (2) atmospheric deposition. Vegetation with large surface areas or that is "sticky" is the best candidate for atmospheric deposition samples. This includes pine (evergreen) needles, moss/ichens, bark, grasses, and deciduous leaves. Soils can provide good samples only if the very top layer is sampled. Also, soil data generally are more difficult to interpret. During the field trial training exercises, vegetation and soil samples were taken both within the plant boundary and extending out beyond the boundary at a distance of $9 \mathrm{~km}$. Samples were collected as prescribed by the protocol (Appendix $\mathrm{C}$ ) that has been successfully used on other environmental monitoring studies. Again, techniques to eliminate cross-contamination between samples were emphasized.

\subsection{WATER, SEDIMENT, AND BIOTA SAMPLING AND HANDLING}

K-25 Site aquatic samples were taken at six locations, on-site, upstream, and downstream; each team participated in the sampling at two or more of the preselected locations. The techniques used in these efforts were similar to those described in Appendix D. A map of the sampling locations used at the K-25 Site is also in Appendix D.

\section{ANALYSIS TECHNIQUES}

\subsection{DESCRIPTION OF SAMPLING ANALYSIS}

Modern analytical methods provide extremely sensitive techniques for measurement of the properties of uranium in environmental samples. Bulk sample analysis techniques measure average properties of uranium in environmental samples, whereas particulate analysis techniques measure properties of selected discrete particles in the samples. Samples in this study were analyzed by isotope dilution mass spectrometry to determine average concentrations and isotopic compositions of the uranium in the samples. This bulk analysis technique is capable of accurately determining the isotopics of parts-per-billion (ppb) quantities of uranium in samples. Screening by rapid, low-cost methods to identify samples containing ${ }^{235} \mathrm{U}$ concentrations with higher-than-normal background may be desirable to identify samples of interest. Such screening may be accomplished either by neutron irradiation techniques that rely upon the counting of delayed neutrons from uranium fission or by microscopic visual observation of fission product tracks that are formed in a sample-mounting substrate, such as polycarbonate or high-purity silica.

The samples in this study were conditioned and the uranium was extracted using standard test procedures. The analyses, including isotopic measurements and assays of uranium, were performed by thermal emission and by inductively coupled plasma-mass spectrometery (ICP-MS). Thermal emission mass spectrometers employed throughout the NWAL were two- and three-stage, high-abundance sensitivity instruments equipped with pulse counting for ion detection. Uranium assays were made by the isotope dilution technique using ${ }^{233} \mathrm{U}$ with an isotopic purity generally of $99.999 \%$. The high sensitivity of pulse counting was required because of the small amounts of uranium (nanograms) extracted from vegetation samples $(10 \mathrm{~g})$. The ${ }^{235} \mathrm{U}$ results are precise to better than $\pm 1 \%$ of the reported value and the accuracy is approximately the same. The instruments were calibrated with appropriate National Institute of Standards and Technology (NIST) standards. Quality assurance was maintained by each NWAL laboratory participating in this field exercise using their standard, in-house quality assurance procedures. 


\subsection{RESULTS AND DISCUSSION}

Complete analytical results are now available to the IAEA through the Safeguards Analytical Network Extended Support Data System; therefore, only the uranium and plutonium results on the various EM samples are in Tables 1 and 5. It is of interest to investigate the effect of HEU on natural uranium in vegetation. Table 6 contains the results of calculating the impact of one part of $93 \%{ }^{235} \mathrm{U}$ on various amounts of natural uranium.

Thus, for example, a pine needle sample with $20 \mathrm{ng}$ of natural uranium having $0.2 \mathrm{ng}$ of HEU would give a $235 / 238$ ratio of 0.017 . Ratios this high are observed only quite close to enrichment facilities (i.e., a few kilometers). Ratios representative of 1 part HEU/1000 parts of natural uranium can be found many kilometers from a large enrichment facility. Because of complexities in sample dispersion and variations of weather conditions, concentration measurements in bulk samples are difficult to correlate with losses from the facility. Uranium concentrations may be necessary, however, to calculate excess ${ }^{235} \mathrm{U}$ in the sample. In the $\mathrm{K}-25$ Site trials, vegetation samples taken in an eastnortheast direction (Fig.3) showed elevated ${ }^{235} \mathrm{U}$ values out to the maximum distance of $8 \mathrm{~km}$. Excess ${ }^{235} \mathrm{U}$ is defined as the quantity of ${ }^{235} \mathrm{U}$ present in the sample in excess of that contributed by natural uranium. It is calculated from the following equation:

$$
X_{235}=\left(A_{s}-A_{n}\right) 100 \cdot C_{u},
$$

where

$$
\begin{aligned}
& \mathrm{XS}_{235}=\text { excess }{ }^{235} \mathrm{U} \\
& \mathrm{A}_{\mathrm{s}} \quad=\text { atom percent }{ }^{235} \mathrm{U} \text { in the sample, } \\
& \mathrm{A}_{\mathrm{n}} \quad=\text { atom percent }{ }^{235} \mathrm{U} \text { in natural }(=0.720), \\
& \mathrm{C}_{\mathrm{u}} \quad=\text { the concentration of } \mathrm{U} \text { in the sample. }
\end{aligned}
$$

It is usually expressed in parts per trillion (ppt). As an example, from Table 6, if the measured abundance of $\mathrm{U}^{235} \mathrm{U}$ is 0.812 and the uranium concentration is $7.5 \mathrm{ppb}$, the calculation is :

$$
\mathrm{XS}_{235}=(0.812-0.7120) / 100 \cdot 7.5=6.9 \mathrm{ppt}^{235} \mathrm{U} \text {. }
$$

The isotopic composition of uranium in bulk samples is, by itself, usually not a definitive indicator of enrichment activity. Plant effluent is usually mixed with enough natural uranium so that the abundance of ${ }^{235} \mathrm{U}$ is below alarm levels (e.g., $3 \%$ for facilities producing fuel for commercial reactors). Only samples taken very close to an enrichment facility producing weapons-grade material will show ${ }^{235} \mathrm{U}$ abundances higher than $3-10 \%$.

It is important to note that close agreement between duplicate samples taken at the same location should not be expected (see Table 1 for $0 \mathrm{~km}$ vegetation). Needles taken from different branches of the same pine tree usually have different ${ }^{235} U{ }^{238} U$ ratios. Some other means of evaluating the data may be required. 
Table 1. Uranium bulk analysis on vegetation: ashed and almost completely dissolved

\begin{tabular}{|c|c|c|c|c|c|c|c|}
\hline \multirow[b]{2}{*}{$\begin{array}{c}\text { Distance } \\
\text { (km) }\end{array}$} & \multicolumn{2}{|c|}{ U conc, $n / g$} & \multicolumn{4}{|c|}{ Isotopic U by TMMS } & \multirow{2}{*}{$\frac{\text { Ratio by ICP-MS }}{{ }^{235} \mathrm{U}^{20 \mathrm{~S}} \mathrm{U}}$} \\
\hline & IDMS & $\begin{array}{l}\text { Delayed } \\
\text { neutron }\end{array}$ & ${ }^{234} \mathrm{U}$ & ${ }^{235} \mathbf{U}$ & ${ }^{20} \mathrm{U}$ & ${ }^{238} \mathrm{U}$ & \\
\hline 0 & 14.2 & 30.9 & 0.0046 & 0.727 & 0.00054 & 99.268 & 0.01061 \\
\hline 0 & 5.678 & & 0.0112 & 1.1974 & 0.00893 & 98.782 & \\
\hline 1 & 6.282 & 32.6 & 0.0111 & 1.2292 & 0.0100 & 98.750 & 0.01111 \\
\hline 3 & 3.101 & 28.5 & 0.0133 & 1.2979 & 0.00297 & 98.680 & 0.01259 \\
\hline 5 & 3.771 & 28.9 & 0.0087 & 0.9799 & 0.00297 & 99.010 & 0.00907 \\
\hline 8 & 2.785 & 16.8 & 0.0101 & 1.0593 & 0.0127 & 98.918 & 0.00888 \\
\hline
\end{tabular}

aThermal ionization mass spectrometers.

bOnly major isotopes are reliable in these samples by ICP-MS.

'Isotope dilution mass spectrometry.

Table 2. Uranium bulk analysis on vegetation: acid leached

\begin{tabular}{|c|c|c|c|c|c|c|c|}
\hline \multirow{2}{*}{$\begin{array}{c}\text { Distance } \\
\text { (km) }\end{array}$} & \multicolumn{2}{|l|}{$\mathbf{U}$ conc, $\mathbf{n} / \mathbf{g}$} & \multicolumn{2}{|c|}{ Isotopic U by TIMS } & \multirow[b]{2}{*}{${ }^{238} U$} & \multicolumn{2}{|c|}{ Ratio $^{235} U P^{234} U$} \\
\hline & IDMS & ${ }^{234} U$ & ${ }^{235} \mathrm{U}$ & ${ }^{236} U$ & & RAW & Excess \\
\hline $\mathbf{0}$ & 0.256 & 0.015 & 1.756 & 0.017 & 98.212 & 117 & 109 \\
\hline 1 & 0.296 & 0.012 & 1.278 & 0.012 & 98.698 & 107 & 85 \\
\hline 3 & 0.189 & 0.012 & 1.198 & 0.017 & 98.773 & 100 & 73 \\
\hline 5 & 0.275 & 0.015 & 1.690 & 0.009 & 98.286 & 113 & 102 \\
\hline 8 & 0.221 & 0.0098 & 0.808 & 0.030 & 99.152 & 82 & 200 \\
\hline
\end{tabular}

Table 3. Particles isolated from vegetation

\begin{tabular}{|c|c|c|c|}
\hline \multirow{2}{*}{$\begin{array}{l}\text { Distance } \\
\text { (km) }\end{array}$} & \multicolumn{3}{|c|}{ Uranium isotopic analysis, atom \% } \\
\hline & ${ }^{234} \mathrm{U}$ & ${ }^{235} \mathrm{U}$ & ${ }^{236} \mathrm{U}$ \\
\hline 1 & & 1.2372 & \\
\hline 1 & 0.0061 & 0.7136 & \\
\hline 1 & 0.0049 & 0.7197 & \\
\hline 1 & & 0.7247 & \\
\hline 3 & & 0.6911 & \\
\hline 3 & & 0.7077 & \\
\hline 3 & & 0.7933 & \\
\hline 3 & & 0.6325 & \\
\hline 3 & & 0.6529 & \\
\hline 5 & 0.1387 & 18.9411 & 0.08797 \\
\hline 5 & & 18.1758 & \\
\hline 5 & & 0.7131 & \\
\hline 5 & 0.0054 & 0.7127 & \\
\hline
\end{tabular}


Table 4. Oak Ridge field trials water and sediment samples

\begin{tabular}{cccccc}
\hline & \multicolumn{5}{c}{ At \% } \\
\hline Sample & U, ng/g & ${ }^{238} \mathrm{U}$ & ${ }^{236} \mathrm{U}$ & ${ }^{235} \mathrm{U}$ & ${ }^{234} \mathbf{U}$ \\
\hline & & Water & & \\
ORK-1 & 0.10 & 99.2417 & 0.0016 & 0.7470 & 0.0098 \\
ORK-2 & 0.14 & 99.2443 & 0.0017 & 0.7437 & 0.0104 \\
ORK-3 & 0.23 & 97.8625 & 0.0116 & 2.0987 & 0.0272 \\
ORK-4 & 1.76 & 99.3592 & 0.0117 & 0.6220 & 0.0071 \\
ORK-5 & 0.58 & 98.4898 & 0.0090 & 1.4842 & 0.0171 \\
ORK-6 & 4.28 & 98.5545 & 0.0101 & 1.4233 & 0.0122 \\
& & & & & \\
& & Sediment & & & \\
ORK-1 & & & & & \\
ORK-2 & & 99.2497 & 0.0023 & 0.7378 & 0.0102 \\
ORK-3 & & 99.2453 & 0.0022 & 0.7415 & 0.0110 \\
ORK-4 & & 99.2142 & 0.0061 & 0.7691 & 0.0100 \\
ORK-5 & & 99.2344 & 0.0107 & 0.7468 & 0.0083 \\
ORK-6 & & 99.1754 & 0.0029 & 0.8104 & 0.0113 \\
\hline
\end{tabular}

Table 5a. Oak Ridge field trials water filter and sediment samples

\begin{tabular}{cccc}
\hline & $\begin{array}{c}\text { Filter samples } \\
\text { [g }\end{array}{ }^{239}$ Pu/g sample (dry wt)] & \multicolumn{2}{c}{$\begin{array}{c}\text { Sediment samples } \\
\text { [g }{ }^{239} \text { Pu/g sample (dry wt)] }\end{array}$} \\
\hline ORK-1 & $1.09 \mathrm{E}-15 \pm 3.27 \mathrm{E}-17$ & ORK-S1 & $6.86 \mathrm{E}-15 \pm 3.39 \mathrm{E}-16$ \\
ORK-2 & $1.40 \mathrm{E}-15 \pm 3.46 \mathrm{E}-17$ & ORK-S2 & $1.40 \mathrm{E}-14 \pm 1.54 \mathrm{E}-16$ \\
ORK-3 & $1.24 \mathrm{E}-14 \pm 1.16 \mathrm{E}-16$ & ORK-S3 & $6.77 \mathrm{E}-13 \pm 1.14 \mathrm{E}-15$ \\
ORK-4 & $1.73 \mathrm{E}-14 \pm 1.14 \mathrm{E}-16$ & ORK-S4 & $3.54 \mathrm{E}-13 \pm 8.19 \mathrm{E}-16$ \\
ORK-5 & $2.34 \mathrm{E}-15 \pm 3.58 \mathrm{E}-17$ & ORK-S5 & $5.00 \mathrm{E}-15 \pm 1.58 \mathrm{E}-16$ \\
ORK-6 & $1.82 \mathrm{E}-13 \pm 2.36 \mathrm{E}-16$ & ORK-S6 & $8.52 \mathrm{E}-12 \pm 3.13 \mathrm{E}-15$ \\
\hline
\end{tabular}


Table 5b. Oak Ridge field trials water filter and sediment samples

\begin{tabular}{lllll}
\hline Samples & ${ }^{299} \mathrm{Pu}$ & ${ }^{240} \mathrm{Pu}$ & ${ }^{241} \mathrm{Pu}$ & ${ }^{24} \mathrm{Pu}$ \\
\hline
\end{tabular}

Filter

$\begin{array}{lrrrr}\text { ORK-1 }^{\mathrm{a}} & & & & \\ \text { ORK-2 }^{\mathrm{a}} & & & & \\ \text { ORK-3 } & 79.87 \pm 0.75 & 10.65 \pm 0.34 & 5.37 \pm 0.27 & 4.11 \pm 0.20 \\ \text { ORK-4 } & 87.77 \pm 0.58 & 9.02 \pm 0.21 & 1.70 \pm 0.12 & 1.51 \pm 0.09 \\ \text { ORK-5 } & & & & \\ \text { ORK-6 } & 94.86 \pm 0.12 & 5.14 \pm 0.03 & 0.09 \pm 0.01 & 0.10 \pm 0.02\end{array}$

\section{Sediment}

ORK-1

ORK-2

ORK-3

ORK-4

ORK-5

ORK-6

$$
80.63 \pm 0.89
$$

$89.78 \pm 0.15$

$91.62 \pm 0.21$

$14.60 \pm 0.43$

$9.58 \pm 0.05$

$7.76 \pm 0.06$

$94.10 \pm 0.03$

$5.73 \pm 0.01$
$2.73 \pm 0.23$

$0.27 \pm 0.01$

$0.27 \pm 0.02$

$2.04 \pm 0.12$

$0.37 \bullet 0.01$

$0.34 \pm 0.02$

$0.13 \pm 0.00$

$0.05 \pm 0.00$

${ }^{a}$ Minor isotopic signals at or below background levels.

Another indicator sometimes found at enrichment sites is ${ }^{236} \mathrm{U}$; uranium-236 does not occur naturally. Its presence, even at low ppm levels, is unequivocal evidence that the uranium has been subjected to a neutron flux. The ${ }^{236} \mathrm{U}$ is often a constituent of feed material of an enrichment plant; this will be the case when spent uranium fuel is recycled through the enrichment process. Note that the presence of ${ }^{236} U$ says nothing about enrichment activities: it only reveals that spent reprocessed nuclear fuel has been returned to the enrichment process. All of the EM samples at the K-25 Site showed low levels of ${ }^{236} \mathrm{U}$.

A powerful technique for aiding interpretations is to calculate the ratio of excess ${ }^{235} U$ to excess ${ }^{234} \mathrm{U}$. "Excess" in this case means the abundance of the two isotopes over what is attributable to natural uranium. For example, for the $3 \mathrm{~km}$ data (Table 2), if the measured ${ }^{235} \mathrm{U}$ abundance is $1.198 \%$, and ${ }^{234} \mathrm{U}$ is $0.012 \%$, the calculation would be:

$$
(1.198-0.72) /(0.012-0.0055)=73 \text {. }
$$

The ratio in natural uranium is $\sim 131$. The value of the excess ${ }^{235} \mathrm{U} /$ excess ${ }^{234} \mathrm{U}$ should, within experimental error, represent some point in the process declared for that facility. For a gaseous diffusion plant, it should reflect the same point on the enrichment cascade, and that point will usually be the one where the most losses occur-often product level uranium.

A similar approach is applied to analyzing data acquired from particles. In this case, however, the contribution from natural uranium is often quite small, and that from the effluent dominates the measured isotopic composition. It can be concluded that, when a number of particles containing uranium having $\sim 19 \%{ }^{235} \mathrm{U}$ are found (Table 3 ), the facility in question has been enriching feed materials to $\mathrm{HEU}$ product. 


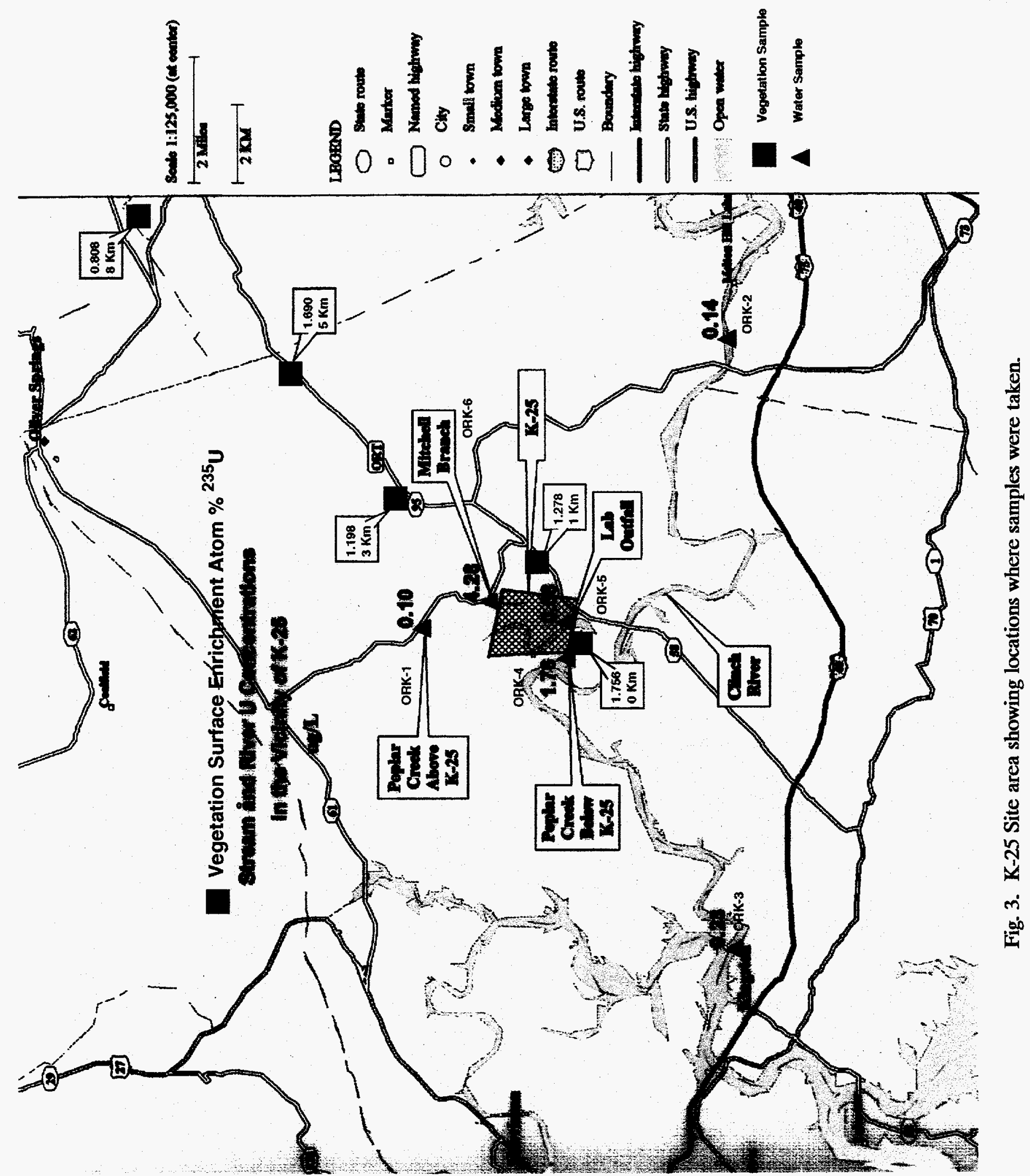


Table 6. Impact of $93 \%$ enriched uranium on the isotope composition of natural uranium

\begin{tabular}{lllllr}
\hline \multicolumn{1}{c}{ Atom \% } & ${ }^{234} \mathrm{U}$ & ${ }^{235} \mathrm{U}$ & ${ }^{238} \mathrm{U}$ & ${ }^{235} \mathrm{U} /{ }^{238} \mathrm{U}$ & ${ }^{235} \mathrm{U} /{ }^{234} \mathrm{U}$ \\
\hline Natural & 0.0055 & 0.7200 & 99.275 & 0.00725 & 131 \\
HEU & 1.00 & 93.00 & 6.00 & 15.5 & 93 \\
& & & & & \\
HEU/natural & & & & & \\
$1 / 20$ & 0.053 & 5.11 & 94.85 & 0.0539 & 96 \\
$1 / 100$ & 0.015 & 1.63 & 98.35 & 0.0166 & 109 \\
$1 / 1000$ & 0.0065 & 0.8112 & 99.18 & 0.00819 & 124 \\
$1 / 10000$ & 0.0056 & 0.729 & 99.265 & 0.00734 & 130 \\
\hline
\end{tabular}

The uranium and plutonium results present in the water and sediment samples are reported in Tables 4 and 5, respectively. These results represent the majority of the data that was produced by SRTC; minor elements reported by SRTC are available to the IAEA by accessing the SANES data base. The plutonium isotopics were measured on a single-stage TIMS based on a NIST design in which isotopic signatures can be established on $10^{8}$ atoms. Uranium isotopics were measured on a three-stage mass spectrometer. Uranium water concentrations were established by fluorometric measurements (Table 4) and the results indicate low $U$ concentrations upstream [i.e., on samples ORK-1 and ORK-2 and higher U concentrations in ORK-6, which is a small stream exiting the K-25 Site (Fig. 3)]. The uranium isotopic results on the filter material are more enriched than the corresponding sediment sample results. The uranium isotopic data indicate the presence of an enrichment site upstream.

The most interesting and revealing environmental monitoring result from the K-25 Site was that of plutonium associated with the water filter and sediment samples. Results of isotope dilution mass spectrometry measurements of plutonium in water filter and sediment samples (Table 5) showed one-half of the filter and two-thirds of the sediments had sufficient plutonium for establishing an isotopic plutonium fingerprint. The ratios of ${ }^{239} \mathrm{Pu} /{ }^{40} \mathrm{Pu}$ vary from 5.52 (ORK-2 sediment) up to 18.46 (ORK-6 filter). The value of 5.52 corresponds ideally to fallout plutonium (note that ORK-2 is upstream of the K-25 Site), whereas the 18.46 (ORK-6) ratio corresponds to low-irradiated plutonium or weapons-grade plutonium. The intermediate ratios between fallout and low irradiated plutonium are further downstream from the ORK-6 site (Fig. 3). This unexpected result indicated that perhaps an error had been made in the analysis-which seemed unlikely since the results for both the filter and sediment for the ORK-6 sample location were in very good agreement-or that some unknown activity involving plutonium had been carried out on the K-25 Site. After checking the credibility of the analytical results, a meeting was held with the K-25 Site management to discuss the findings. K-25 Site management explained that several years ago, some Hanford reactor material containing very low concentrations of plutonium was brought to the K-25 Site. As a result of several small release mechanisms during processing, some of this low-irradiated plutonium was deposited into a waste pond located near the stream that was sampled (ORK-6) during the field trial exercise. This sampling occurred during an all-day, heavy rain. Under these conditions, it is very likely that the small waste pond overflowed into the stream, resulting in some plutonium transferring from the pond to the stream. Additional checking showed that the observed isotopic fingerprints are consistent with plutonium produced at the Hanford site. 
Overall, the environmental sample results from the K-25 Site demonstrated clearly and decisively that HEU and LEU enrichment operations can be detected with both bulk and particulate techniques. The plutonium result is extremely significant in that it obviously supports the concept that EMs have substantial application in the detection of unexpected (undeclared) activities at a nuclear facility. It also suggests how an EM "anomaly" might be handled; first, check the analysis, and then meet with the facility operator to explore possible explanations for the observed results. 

Appendix A

AGENDA, ATTENDEES, AND SAMPLE TEAM COLLECTION ASSIGNMENTS FOR THE IAEA ENVIRONMENTAL MONITORING FIELD TRIAL WORKSHOP 

Appendix A

AGENDA

IAEA ENVIRONMENTAL MONITORING FIELD TRIALS WORKSHOP

OAK RIDGE, TENNESSEE - MARCH 22-25, 1994

\section{MARCH 22}

7:45 AM Pickup at Hampton Inn

8:15 AM Badging at Portal \#2, K-25 Site

MEETING LOCATION: K-25 SITE BLDG. K-601 CONFERENCE ROOM

8:30-8:45 Introduction/Site Welcome

8:45-9:00 IAEA Environmental Fields Trials/

U.S. Field Trials Status

9:00-9:30 Environmental Monitoring at Uranium Enrichment Plants

9:30-9:45 Safeguards Analytical Network

Extended Support

9:45-10:00 Analysis techniques for field trial samples

10:00-10:15 Break

10:15-10:45 Collection of Environmental Samples for

Detection of Undeclared Nuclear Activities

10:45-11:00 Analytical Techniques for Detection of Enriched Uranium

11:00-12:00 Sampling Media and Equipment

Swipe Samples

Vegetation, Soil Sampling

Water Sampling

12:00- 1:00 Lunch

1:00 - 1:30 Health Physics Briefing on Site Controls
DOE/MMES

J. Cooley/IAEA

K-25 Facility Rep.

D. Hembree

W. Belew

K. Nicholson

J. Toole

G. Cheney/AFTAC

D. Smith/ORNL

A. Boni/SRTC

Craig Reed/K-25 
1:30 - 2:30 PLANNING THE SAMPLING CAMPAIGN

- K-25 site characteristics

- Using weather, hydrology and site data

ORNL

- Identifying sample types and number to

SRTC/ORNL be collected

- Selecting off-site and on-site sample points

SRTC/ORNL

- Selecting swipe sample points in the facility

SRTC/ORNL

- Logistics - site transportation,

ORNL/AFTAC

team assignments

- Information required for IAEA working papers

ORNL

IAEA

$2: 30-2: 45 \quad$ Break

2:45 - 4:30 DEMONSTRATIONS OF SAMPLING EQUIPMENT AND PROCEDURES

- Vegetation sampling and handling procedures

ORNL

- Soil sampling and handling procedures

ORNL

- Water sampling and handling procedures

SRTC

- Swipe sampling and handling procedures

AFTAC

- Using GPS equipment to locate sampling points

SRTC/ORNL

\section{MARCH 23}

7:45 AM Pickup at Hampton Inn

8:15 AM Badging at Portal \#2, K-25 Site

\section{WORKSHOP LOCATION: K-25 SITE BLDG. K-601 CONFERENCE ROOM}

8:30 - 9:00 Staging and dispatching of teams

9:00 - 12:00 Sample Collection by teams

Team A: Collection of Vegetation/Soil Samples

Team B: Collection of Swipe Samples

Team C: Collection of Water Samples

12:00 - 1:00 Lunch B॥dg. K-601

MARCH 24

1:00 - 4:00 Sample Collection by teams

Team A Collection of Swipe Samples

Team B: Collection of Water Samples

Team C: Collection of Vegetation/Soil Samples 


\section{MARCH 24}

7:45 AM Pickup at Hampton Inn

8:15 AM Badging at Portal \#2, K-25 Site

WORKSHOP LOCATION: K-25 SITE BLDG. K-601 CONFERENCE ROOM

8:30 - 9:00 Staging and dispatching of teams

9:00 - 12:00 Sample Collection by teams

Team A: Collection of Water Samples

Team B: Collection of Vegetation/Soil Samples

Team C: Collection of Swipe Samples

12:00 - 1:00 Lunch Bldg. K-601

1:00 - 4:30 Critique of Environmental Sampling Workshop

- Modification of procedures

- Modification of Sampling Kits

\section{MARCH 25}

7:45 AM Pickup at Hampton Inn

8:15 AM Badging at Portal \#2, K-25 Site

WORKSHOP LOCATION: K-25 SITE BLDG. K-601 CONFERENCE ROOM

8:30-4:00 Planning Exercise for Other Field Trials 


\section{ATTENDEES}

Name

Jill N. Cooley

Wendell L Belew

Bill McConachie

Michio Hosoya

Andrzej PietruszewskI

Dorel Popescu

Kantika Sirisena

Rich Holdren

Charles Miller

Doyle Hembree

Gene Cheney

Al Boni

Giancarlo Zuccaro-Labellarte

David Smith

Erwin Kuhn

David Donohue

Harley Ross

David Hayes

James Huenefeld

Tamas Biro

Jorge Vallejo Luna

Ibrahim Cherradi

Joe Toole

Ken Nicholson

Malcolm Pendergast

Richard Coleman

Doug Duckworth

Eddy McBay

Joel Carter
Organization

Martin Marietta/Y-12

Martin Marietta/Y-12

Lawrence Livermore Nat'l Lab

IAEA

IAEA

IAEA

IAEA

PNL

LANL

Martin Marietta/Y-12

AFTAC

SRTC

IAEA

ORNL

SRTC

IAEA

ORNL

SRTC

IAEA

IAEA

IAEA

IAEA

AEA Technology

AEA Technology

SRTC

ORNL

ORNL

ORNL

Martin Marietta/Y-12
Phone

615-576-5650

615-574-3626

510-423-3501

43-1-2360-1813

43-1-2360-6295

43-1-2360-2068

43-1-2360-1983

509-376-2242

505-667-8415

615-574-2604

407-494-2822

803-725-2628

43-1-2360-2141

615-574-2449

803-725-3810

43-1-2254-72251-566

615-574-713137

803-725-3810

43-1-2360-1942

43-1-2360-6437

43-1-2360-2104

43-1-2360-2054

44-235-436343

44-235-43439

803-725-242

615-574-2455

615-576-6296

615-576-6296

65-241-4773 


\section{SAMPLE COLLECTION TEAM ASSIGNMENTS}

NAME

Kantika Sirisena

Tamas Biro

James Huenefeld

Bill McConachie

\section{Organization}

$\underline{\text { Team A }}$

IAEA

IAEA

IAEA

LLNL

$\underline{\text { Team B }}$

Erwin Kuhn

Giancarlo Zuccaro-Labellarte

Jorge Alberto Vallejo

Ibrahim Farid Cherradi

Charles Miller
IAEA

IAEA

IAEA

IAEA

LANL

\section{$\underline{\text { Team } \mathrm{C}}$}

Andrezi Edward Peitruszewski

IAEA

Michio Hosoya

IAEA

David Lee Donohue

IAEA

Rich Holdren

PNL

Building Access Schedule for Swipe sample collection:

Each Swipe sample collection team will be accompanied by Joel Carter/ORNL and Gene Cheney/AFTAC plus one or two others from DOE installations.

Sampling locations in Bldg. K-25 will be: $303-7$ and 3024 operating floor line recorder station and trap area.

Sampling locations in Bldg. K-1220 will be: the sample cart, product freeze-out station, and sample station in the Mass Spectrometry Laboratory.

Team B: Wednesday March 23, 9:00 A.M., Building K-25; 10:30 A.M., Building K-1220

Team A: Wednesday March 23, 1:00 P.M., Building K-25; 2:30 P.M., Building K-1220

Team C: Thursday March 24, 9:00 A.M., Building K-25; 10:30 A.M., Building K-1220 

Appendix B

SWIPE SAMPLE COLLECTING PROCEDURES 


\section{Appendix B}

\section{SWIPE SAMPLE COLLECTING PROCEDURES}

The following procedures will be used for sample collection at each sampling area:

1. Preparation:

a. Place a piece of aluminum foil or similar clean material on a flat surface for use as a work area.

b. Empty contents of sampling kit onto work surface.

c. The collector and assistant will wipe their hands with one cloth wipe. This wipe will be double bagged and used as a control sample.

d. Put on clean gloves.

e. Place labels on the seven smaller bags, mark the sample bags, and fill out the sample collection work sheet.

\section{Sample Collection:}

a. During the collection, the collector will be considered "dirty."

b. The assistant will be considered "clean."

c. Ensure that the assistant never comes in direct contact with the sample.

d. You will be taking six wipes, each covering an equal portion of the sampling area.

e. Each wipe should contain an equal amount of sample.

f. If possible, assay each wipe for beta/gamma and alpha activity, and record the results on the sample bag.

g. Take one sample wipe, then proceed to step three, Sample Bagging.

h. Repeat for remaining five wipe samples.

\section{Sample Bagging:}

a. Be careful not to touch the assistant's gloves or the outside of the bag.

b. Place the collected sample into the pre-marked bag being held by the assistant.

c. If the assistant's gloves are touched, they must be changed immediately.

d. If the outside of the bag is touched, it will be sealed and bagged again. This discrepancy will be noted on the sample bag.

e. The assistant will seal the sample bag, place the bagged sample into a second bag, and reseal it.

f. The double-bagged samples will be placed in the large clean plastic bag marked for each sampling location.

4. Upon completion of the sample collection, all used and unused supplies will be discarded to prevent possible cross-contamination. Bagged samples will be removed from the area and placed in proper storage until shipment.

5. The same collection procedure will be followed for each sampling area. At a minimum, the collector and assistant will change gloves after the samples have been bagged and before beginning a collection in a new sampling area. 


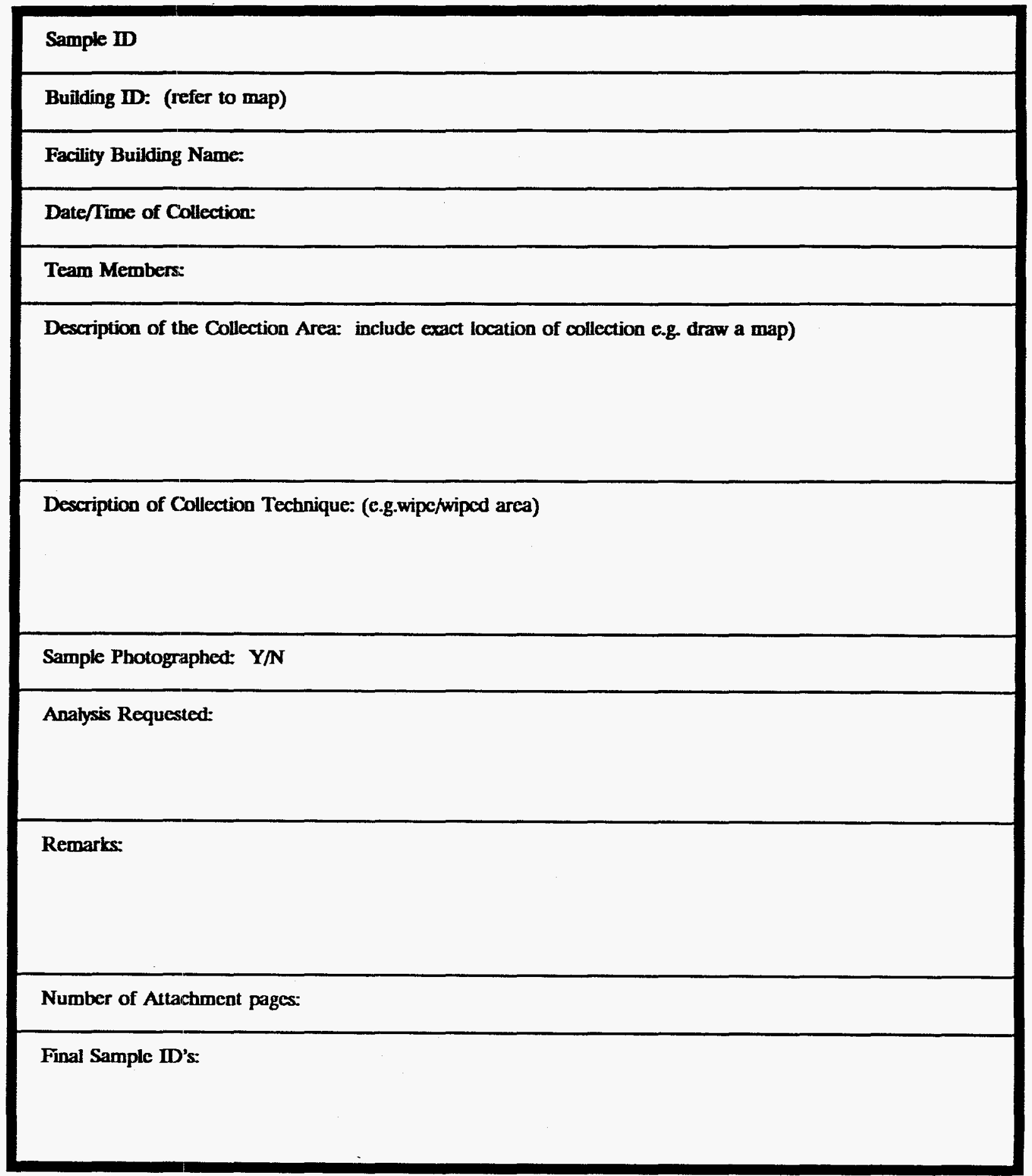


Appendix C

PROCEDURE FOR VEGETATION AND SOIL SAMPLING 

Appendix C

PROCEDURE FOR VEGETATION AND SOIL SAMPLING

Equipment:

1. Lint-free gloves

2. Polyethylene bags ( 3 sizes)(one set per sample)

3. Bar code labels

4. Position finder

5. Data sheets

6. Soil and bark sampling tool (as needed)

Priority of Sample Types:

1. Pine needles

2. Cedar foliage

3. Other evergreen foliage

4. Mosses and lichens

5. Grasses, shrubs, deciduous leaves

6. Soil and bark

Collecting Samples:

1. Select tree, etc., from which you will take samples.

2. Find geographic position and record.

3. Put on lint-free gloves.

4. Select polyethylene bags.

5. Affix bar code to inner and secondary bags.

6. Remove desired amount of vegetation and put it in the bag. About $0.5 \mathrm{~L}$ of vegetation is required per sample. If more than two replicate analyses are desired (as when samples will be archived), more than one bag should be filled. Soil samples should be $20-100 \mathrm{~g}$.

7. Seal inner bag.

8. Insert bag in secondary container (larger bag).

9. Seal secondary container.

10. Remove gloves.

11. Dispose of gloves; they can be carried in the secondary bag if desired.

12. Enter information on log sheet, including bar code. 

Appendix D

AQUATIC SAMPLING METHODS 

Appendix D

\section{AQUATIC SAMPLING METHODS}

\section{Purpose:}

The purpose of this phase of the training is to orient IAEA inspectors in the collection of water and sediment samples in support of safeguards. The effluents from many nuclear operations are discharged to surface waters. If the presence of these effluents can be detected by special measurement techniques, then an assessment can be made as to the type of nuclear activity that may be occurring.

Background:

Four types of samples will be collected during this training session: (1) a water filter sample to concentrate dissolved and particulate matter from a large volume of water $(-300 \mathrm{~L})$; (2) a sediment sample; (3) water samples; and (4) biota if present. In addition to collecting samples, some field environmental data also are collected and a field data sheet is to be completed.

The water filters, sediment, and biota samples will be analyzed for gamma emitting radionuclides, plutonium, and uranium isotopic ratios. The gamma emitting radionuclides are measured in an underground ultra low level counting facility to determine the presence of activation and fission products. Radiochemical separations for isolating $\mathrm{Pu}$ and $\mathrm{U}$ are then performed on the samples and the isotopic abundances are measured by alpha spectrometry and high-sensitivity multistage surface ionization mass spectrometry.

The water samples will be analyzed for tritium concentrations by ultra-low background gas proportional counting. A stable element concentration fingerprint for each location will be measured by Inductively Coupled Plasma Mass Spectrometry (ICP/MS).

Field data are collected to establish environmental conditions during the sample collection. These data assist in the interpretation of the analytical measurements. 


\section{TYPES OF EQUIPMENT USED}

\section{High-Volume Water Sampler:}

High-volume water samples are taken with the Savannah River Technology Center (SRTC) portable water sampler system and a special filter cartridge. The SRTC portable water sampler system consists of the case containing the water pump, flow meter and connecting tubing, and a battery unit for operating the pump. From the diagram, it is easy to see that the operation is straightforward in the field. The inlet tube with the strainer on the end is placed in the water and the other end is attached to the inlet side of the filter cartridge and the outlet side of the filter cartridge is attached to the tube from the flow meter. This type of operation reduces the possibility of cross-contamination by minimizing the number of system components exposed to the water prior to passing through the filter cartridge. To further reduce the possibility of cross-contamination, the system is flushed without the filter in the system by using the bypass connectors in the case.

Sediment:

The sediment sample is usually collected by employing a core tube. The sample is taken by inserting the core tube into the sediments $-15 \mathrm{~cm}$, capping off the open end, and carefully withdrawing the tube. Sometimes several tries are needed to obtain a sample. We are trying to get at least $10 \mathrm{~cm}$ of sediment into the core tube. Sometimes the sample is collected by hand and placed into a bottle. When the sample is collected by hand, the top 5 to $6 \mathrm{~cm}$ are collected for a total of $-100 \mathrm{~cm}^{3}$.

Water Samples:

These water samples are usually collected by dipping the bottles into the water, with the mouth facing upstream. Each bottle is rinsed a minimum of 2 times by filling the bottle about $3 / 4$ full, capping, shaking, and pouring out. After the rinsing process is completed, the bottles are filled to within $1 / 2 \mathrm{~cm}$ of the top before capping.

\section{Biota:}

Biota samples are usually collected near the water's edge and should consist of algae. Green filamentous algae is the preferred type. The samples are collected by hand using throwaway gloves, and $-100 \mathrm{~cm}^{3}$ needs to be collected.

\section{Field Data:}

Field data are collected while the water filter samples are being taken and the data are recorded on the field data sheet. The field data include measurements of: Water Quality (water conductivity and temperature); Meteorological Data [relative humidity (maybe wet bulb) and dry bulb air temperature]; GPS location (latitude and longitude), and sometimes barometric pressure. Other notes recorded should include: whether it was raining, whether the water looked muddy or clear; and whether the river or stream flow looked normal or was higher or lower than normal. A sketch of the location showing direction of flow, on which side of the river the sample was collected, and a prominent feature such as a bridge should be included.

\section{Field Data Sheet:}

The field data sheet permits the recording of environmental data, sample IDs, filter volume flow, comments, and other data. 
ETS AQUEOUS SAMPLING CHAIN-OF-CUSTODY FORM

Site ID:

Date:

Time:

Team Members:

Description of Collection Area. (Draw a map. Show flow direction, side of river sampled, and a prominent feature.)

Environmental Field Data

GPS LATITUDE

Barometric Pressure LONGITUDE

Meteorological Data:

Dry Bulb: Wet Bulb or Relative Humidity

Rain (Yes/No)

Water Quality: Temperature

Muddy/Clear: Constant, Rising, Falling

Conductivity

Pictures taken (of sampler and river, up and down river, and sediment location) _

Water Sample:

$$
\text { Country }
$$

Sample ID:

Sample ID:

Sample ID:

Sample ID:

Receivin
Country
$\square$
$\square$

Filter Sample:

Filter ID:

Cartridge ID:

Receiving

Begin Vol:

End Vol:

Total Vol

Filter ID:

Cartridge ID:

Begin Vol:

End Vol:

Total Vol

Biota

Receiving

Sample ID:

Sample ID:

Sample ID:

Country

Sample ID:

Sample ID:

Sample ID:

$$
\text { Country }
$$

Receiving

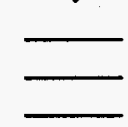



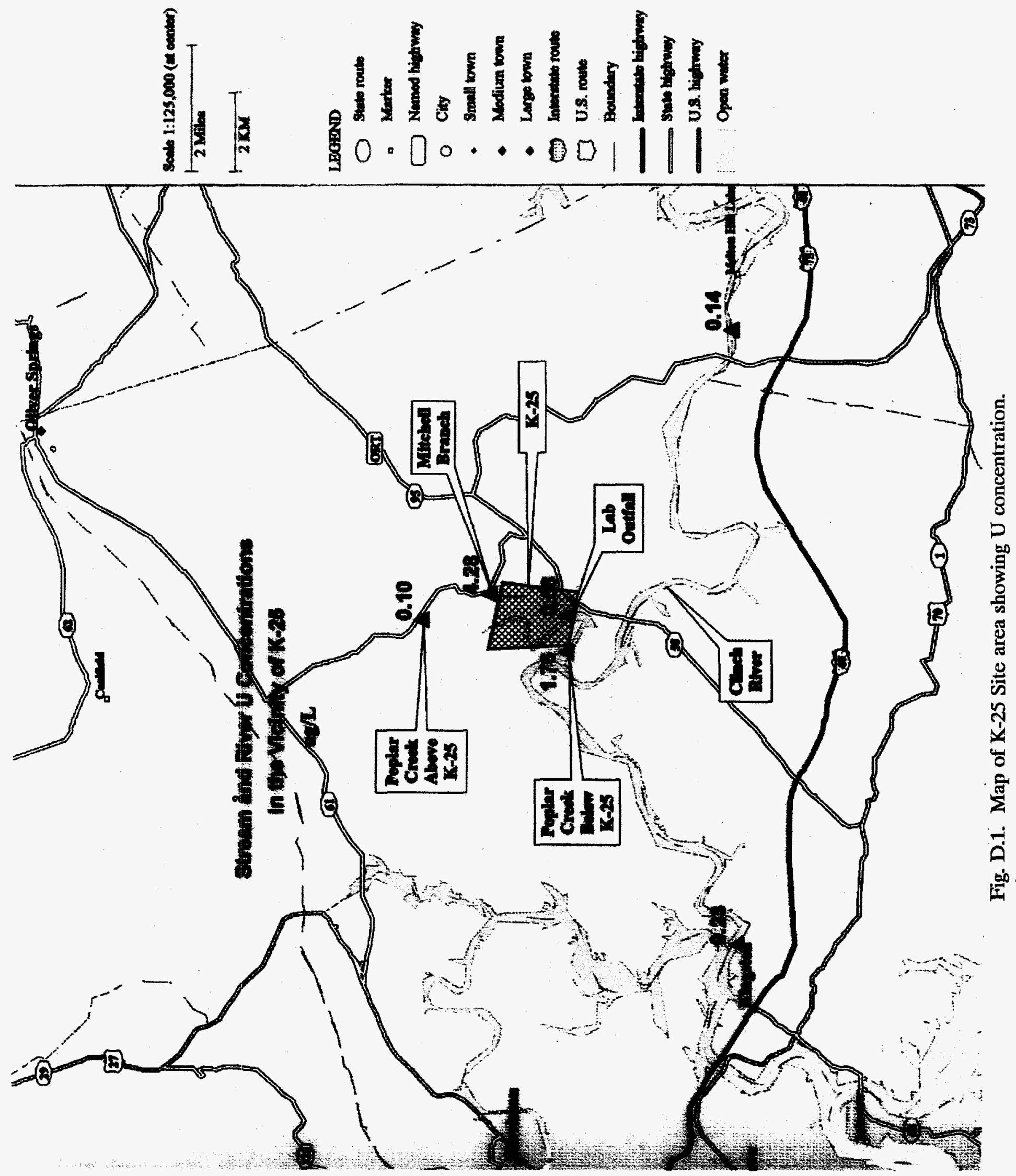


\section{BIBLIOGRAPHY}

J. K. Abaychi and Y. Z. Mustafa, "The Asiatic Clam, Corbicula fluminea: An Indicator of Trace Metal Pollution in the Shatt al-Arab River, Iraq," Env. Poll. 54(2), 109 (1988).

D. C. Adriano et al., "Plutonium Contents and Fluxes in a Soybean Crop Ecosystem Near a Nuclear Fuel Chemical Separations Facility," Jour. Env. Qual. 11(3), 506 (1982).

E. A. Bondietti, F. O. Hoffman, and L.L. Larsen, "Air-to-Vegetation Transfer Rates of Natural Submicron Aerosols," Jour. Env. Radioact. 1(1), 5 (1984).

A. L. Boni et al., Safeguards Field Test in the Coastal Waters of Sweden, draft.

J. A. Carter et al., "Isotope Dilution Resin Bead Mass Spectrometry-An Ultratrace Technique for Measuring Nuclides in Three-Mile Island Water," Jour. Env. Anal. Chem. 8, 241-248 (1980).

D. A. Cataldo et al., "Foliar Absorption of Transuranic Elements: Influence of Physicochemical Form and Environmental Factors," Jour. Env. Qual. 9(3), 364 (1980).

G. Hartmann and $\mathrm{K}$. Bachman, "Pu and Other Trace Elements in/on Plants," Jour. Env. Radioact. 8(1), 21 (1988).

G. Harbottle, R. Miller, and E. V. Sayre, "Pine Needles as Sensors of Atmospheric Pollution," Env. Monit. and Assess. 2(3), 27 (1982).

J. J. Koranda and W. L. Robison, "Accumulation of Radionuclides by Plants as a Monitor System," Env. Health Persp. 27, 165 (1978).

F. C. Kornegay et al., Oak Ridge Reservation Annual Site Environmental Report for 1993, ES/ESH-47, Martin Marietta Energy Systems, Inc., November 1994.

F. C. Kornegay et al., Oak Ridge Resenvation Environmental Report for 1992, ES/ESH31/V1/V2, Martin Marietta Energy Systems, Inc., September 1993.

A. McCormick, "Thermal Ionization Mass Spectrometry for Small Sample Analysis of Uranium and Plutonium," Appl. Radiat. Isot. 43, 271-278 (1992).

K. W. Nicholson et al., Environmental Sampling for Detection of Undeclared Nuclear Activities, AEA/CS/11100063001/Issue 1, December 1993.

D. H. Smith, R. L. Walker, and J. A. Carter, "Sampling and Analysis of Radioactive Solutions," Anal. Chem. 54, 827A-832A (1982). 


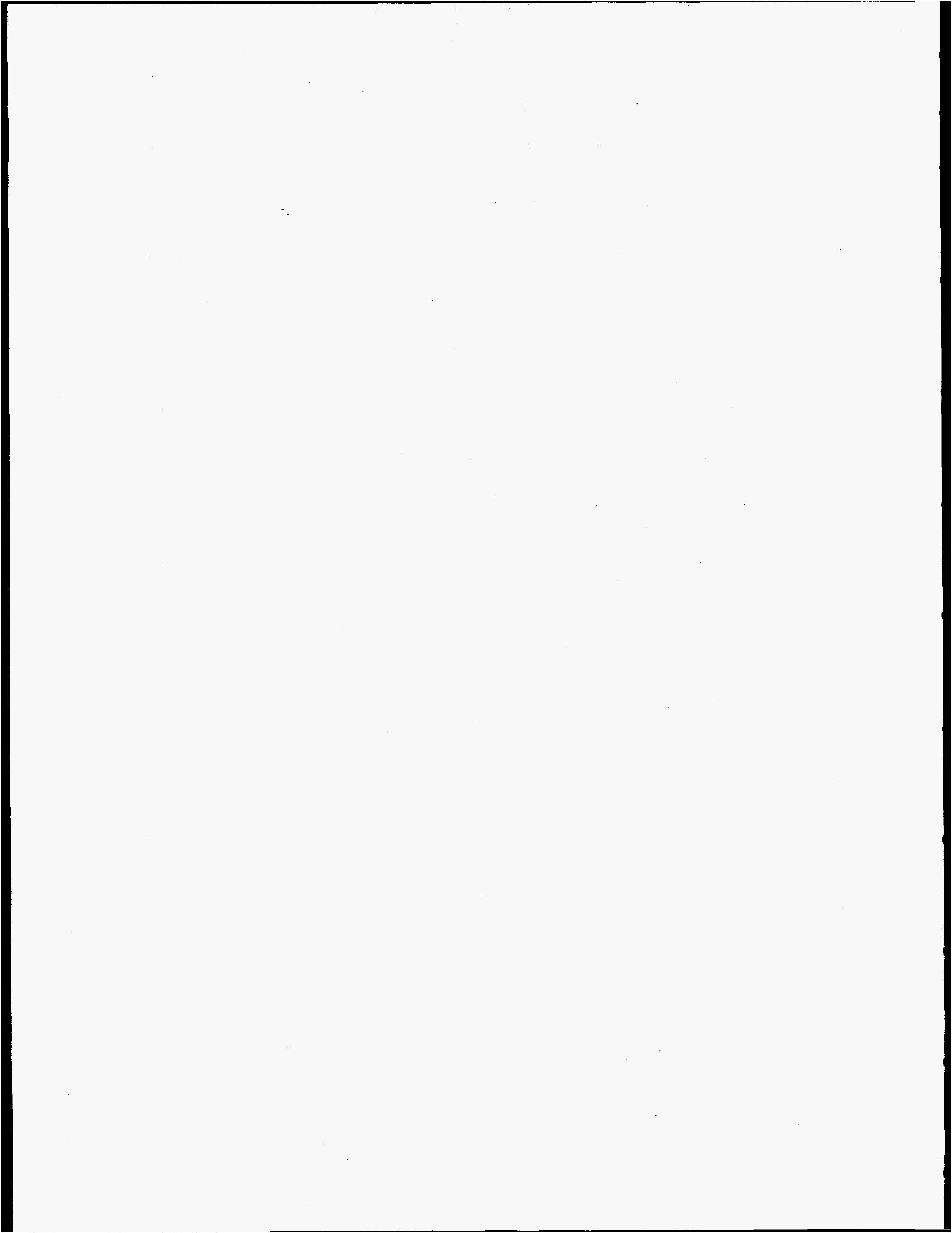




\section{ACRONYMS AND INITIALISMS}

$\begin{array}{ll}\text { DOE } & \text { Department of Energy } \\ \text { EM } & \text { Environmental Method } \\ \text { EPA } & \text { Environmental Protection Agency } \\ \text { HEU } & \text { highly enriched uranium } \\ \text { IAEA } & \text { International Atomic Energy Agency } \\ \text { ICP } & \text { inductively coupled plasma } \\ \text { ICP-MS } & \text { inductively coupled plasma-mass spectrometry } \\ \text { LEU } & \text { low enriched uranium } \\ \text { NIST } & \text { National Institute of Standards and Technology } \\ \text { NSPO } & \text { National Security Program Office } \\ \text { NWAL } & \text { U.S. Network of Analytical Laboratories } \\ \text { ORR } & \text { Oak Ridge Reservation } \\ \text { ppb } & \text { parts per billion } \\ \text { ppm } & \text { parts per million } \\ \text { ppt } & \text { parts per trillion } \\ \text { SAGSI } & \text { Standing Advisory Group on Safeguards Implementation } \\ \text { SOPs } & \text { standard operating procedures } \\ \text { SRTC } & \text { Savannah River Technology Center } \\ \text { TIMS } & \text { thermal ionization mass spectrometers } \\ \text { TSCA } & \text { Toxic Substances Control Act }\end{array}$





\section{DISTRIBUTION}

1-31. Martin Marietta Energy Systems. Inc.

J. A. Carter (3)

R. S. Eby (3)

M. H. Ehinger (2)

D. M. Hembree

A. S. Quist (3) ${ }^{*}$

H. H. Ross (16)

R. E. Upchurch

Laboratory Records

NSPO Central Files - F3-3 (RC)

32. U.S. Department of Energy,

Oak Ridge Operations

J. C. Hall, Asst. Manager of Research and Development

*Two copies for DOE Office of Scientific and Technical Information. 